\title{
Determining Students' Conceptual Understanding Level of Thermodynamics
}

\author{
Hakan Saricayir ${ }^{1}$, Selahattin $\mathrm{Ay}^{1}$, Arif Comek ${ }^{2}$, Gokhan Cansiz ${ }^{3}$, Musa Uce ${ }^{1}$ \\ ${ }^{1}$ Chemistry Education, Marmara University, Istanbul, Turkey \\ ${ }^{2}$ Science Education, Marmara University, Istanbul, Turkey \\ ${ }^{3}$ Education Faculty, Yeditepe University, Istanbul, Turkey \\ Correspondence: Hakan Saricayir, Chemistry Education, Marmara University, Istanbul, Turkey
}

Received: February 28, 2016 Accepted: March 7, 2016 Online Published: March 22, 2016

doi:10.11114/jets.v4i6.1421

URL: http://dx.doi.org/10.11114/jets.v4i6.1421

\begin{abstract}
Science students find heat, temperature, enthalpy and energy in chemical reactions to be some of the most difficult subjects. It is crucial to define their conceptual understanding level in these subjects so that educators can build upon this knowledge and introduce new thermodynamics concepts. This paper reports conceptual understanding levels of high school students of common thermodynamics subjects such as heat, temperature, enthalpy and energy changes in chemical reactions. The sample of the study was composed of 418 randomly selected students from 11 different high schools. A cross sectional survey model was employed in this study. Data were collected through the Conceptual Understanding Test (CUT), which consists of 16 questions. Cronbach's alpha reliability coefficient for the test was 0.72 . Besides, interviews were conducted with 10 students to get qualitative data about their beliefs on the subject. The results of the study indicated that students' level of conceptual understanding in thermodynamics concepts is very low. It was observed to be especially low for the concepts of (1) relationship between energy, enthalpy and bonds in chemical reactions, (2) energy and catalysts in chemical reactions, (3) changes in heat, temperature and enthalpy during change of state, and (4) the relationship between heat, temperature, mass and specific heat. Most of the students in this study do not fully understand common thermodynamics concepts although they have been studying these topics since primary school.
\end{abstract}

Keywords: conceptual understanding, heat and temperature, enthalpy, energy changes in chemical reactions, catalyst

\section{Introduction}

Chemical thermodynamics is one of the most popular yet notoriously difficult chemistry subjects that abounds in misconceptions for students (Anderson, Taraban, \& Sharma, 2005; Brook, Briggs, Bell, \& Driver, 1984; Cotignola, Bordogna, Punte, \& Cappannini, 2002; Erickson, 1979, 1980; Goedhart \& Kaper, 2002; Grayson, Harrison, \& Treagust, 1995; Junglas, 2006; Laburú \& Niaz, 2002; Lewis \& Linn, 1994; Linn \& Songer, 1991; Meltzer, 2004; Mulop, Yusof, \& Tasir, 2012; Patron, 1997; Schönborn, Haglund, \& Xie, 2014; Sokrat, Tamani, Moutaabbid, \& Radid, 2014; Sozbilir, 2001, 2003; Sözbilir, 2004). Comprising a wide range of fundamental concepts such as heat, temperature, enthalpy and energy changes, thermodynamics holds a crucial role in understanding all types of chemical phenomena, making it so popular and also challenging for students (Jasien \& Oberem, 2002; Krummel, Sunal, \& Sunal, 2007; Olgun, 2008; Pétursson, 2003; Sözbilir, 2004; Yeo \& Zadnik, 2001).

The main challenge for students is the level of abstraction of concepts in thermodynamics (Ayyildiz \& Tarhan, 2012; Ben-Zvi, Eylon, \& Silberstein, 1988; Bergquist \& Heikkinen, 1990; Carson \& Watson, 2002; Chiu, 2007; Cox, Belloni, Dancy, \& Christian, 2003; Huang \& Gramoll, 2004; Junglas, 2006; Mulop et al., 2012; Patron, 1997). Also, because these concepts are part of learners' everyday experiences, they lead to misinterpretation of the topics when they are introduced in science classes (Ben-Zvi et al., 1988; Bergquist \& Heikkinen, 1990; Duschl \& Gitomer, 1991; Herron, 1996; Thomas \& Schwenz, 1998). Numerous studies on conceptual understanding of these chemistry topics have revealed that students experience many problems with chemical thermodynamics. One of the problems is that many students cannot distinguish the concepts of heat and temperature (Lewis \& Linn, 1994; McDermott, 2003; Paik, Cho, \& Go, 2007). These students consider "heat" and "temperature" to have the same meaning and use them interchangeably (Erickson, 1979; Grayson et al., 1995; Kesidou \& Duit, 1993; Niaz, 2006; Schönborn et al., 2014; Wiser \& Carey, 1983; 
Yalçınkaya, Taştan, \& Boz, 2009). According to empirical studies 12-year-old students believed that heat is matter like air or vapour and that heat is the opposite of temperature and temperature of a substance depends on its volume and size (Erickson, 1979). Many middle school students believed a metal can conduct, absorb or hold cold better than other materials and so aluminium foil, not wool or cotton, is the best choice to keep cold objects cold (Lewis \& Linn, 1994). Many grade 10 students were found to believe that temperature, unlike heat, is a variable that can be measured and quantified, and most stated that temperature measures or quantifies heat, while others stated that temperature can be measured but heat cannot be (Kesidou \& Duit, 1993). Another problem emerges from the relationship between chemical bonding and reaction energies. Students have problems determining exothermic and endothermic reactions as well as bond energies. They were found to believe matter should be heated to burn (like a candle), and thus combustion reactions are endothermic while some who thought bond-breaking is an exothermic reaction and bond-formation is an endothermic reaction (Boo, 1998). Problems with concepts in thermodynamics continue at university level as well. Undergraduates studying thermodynamics were found to hold several misunderstandings, some of which are bond breaking releases energy, bond making requires energy, endothermic reactions cannot be spontaneous, and endothermic or exothermic reactions occur fast (Sozbilir, 2001).

The existing research showed that students' conceptualizations are quite different from the science ideas to be learned in thermodynamics and hence have a marked influence on their understanding of the related scientific ideas. In this respect, determining students' conceptual understanding levels in the area of thermodynamics becomes crucial for promoting conceptual understanding. Conceptual understanding can be defined variously. It is generally defined as learning with understanding (Driver et al., 1994). It is often contrasted with declarative knowledge learning, in which the learner should simply memorize a relationship between things, events, or processes (Darmofal, Soderholm, \& Brodeur, 2002). To some conceptual understanding entails more than rote memorization of relationships; it requires the ability to apply previous learning across some kind of previously unexpected experiences (Smith \& Ragan, 1999). Thus, it can be defined as Ausubelian meaningful learning rather than rote learning. Conceptual understanding includes association, comparison, assimilation and reorganization of new knowledge with existing knowledge and transferring it to solve the new problematic situations. Conceptual understanding is predicated upon the reorganization of existing knowledge as propounded by the cognitive constructivist theory of learning to some (Duit, 1999; Piaget, 1951; Posner, Strike, Hewson, \& Gertzog, 1982; Tobin, Tippins, \& Gallard, 1994). According to Piaget, (1985) people use schemes to interpret new experiences concerning learners' existing schemata through a process of assimilation and accommodation. Accordingly, students construct their own naive concepts by observing and investigating the world (Baser, 2006; Cahyadi \& Butler, 2004; Calik \& Ayas, 2005; Carson \& Watson, 2002; Chiu, 2007; Osborne \& Freyberg, 1985; Pine, Messer, \& St. John, 2001). Conceptual understanding might also be interpreted within the socio-cultural constructivist theory of learning (Vygotsky, 1980; Duit, 1999; Kabapınar, 2006). According to Vygotsky, 'learning awakens a variety of internal development processes that are able to operate only when the child is interacting with people in his environment and in co-operation with his peers' (Vygotsky, 1980 p;90). Learning occurs when the knowledge found in the social plane is internalized by the learner. Vygotskian socio-cultural constructivist view has been defined by Tharp and Gallimore, (1988) as 'guided reinvention' where a more able peer or teacher is regarded as guides in one's learning. Learner's existing knowledge is expected to be developed toward the scientific knowledge. Unless prior knowledge is properly associated with new knowledge, children may fail to correctly grasp new concepts, which impedes meaningful learning (Ausubel, Stager, \& Gaite, 1968; Bodner, 1986) and leads to misconceptions (Krishnan \& Howe, 1994; Özkaya, Üce, Saricayir, \& Sahin, 2006; Prawat, 1989). In order to preclude formation of wrong associations and foster a correct understanding of these topics, it is necessary to make learning meaningful (Bergquist \& Heikkinen, 1990; Chiu, 2007; Roth \& Lucas, 1997). An awareness of the fact that misconceptions prevent meaningful learning has paved the way for studies aiming to determine students' levels of understanding in science concepts including those of chemistry (Cahyadi \& Butler, 2004; Fleer, 1999; Palmer, 1999; Pfundt \& Duit, 1988).

Conceptual understanding offers the potential to engage students in learning (Wiggins, McTighe, Kiernan, \& Frost, 1998) and promote learning and thus have become an area of interest for educational research. Gaining insights into students' existing conceptions might help educators design teaching approaches targeting conceptual understanding. These include strategies based on confronting students with the inadequacy of their ideas and strategies based on building bridges from a situation where students' intuitive responses are consistent with scientific statements to the scientific idea to be learned. Determination of students' conceptual level in thermodynamics topics such as heat, temperature, enthalpy and energy changes in chemical reactions might also help educators in selecting the more suitable teaching strategy to promote conceptual understanding.

\subsection{Purpose and Research Questions}

This study mainly aimed to determine high school students' conceptual understanding levels of common thermodynamics subjects such as heat, temperature, enthalpy and energy changes in chemical reactions. This research 
study analysed data from the Conceptual Understanding Test (CUT) and the interviews with students. It also focused on students' conceptual understanding levels in common thermodynamics topics. In particular, the following research questions were addressed;

(1) What are the students' conceptual understanding levels of heat, temperature, enthalpy, energy in chemical reactions and catalysts?

(2) What are the areas that students misunderstand or lack any understanding about heat, temperature, enthalpy, energy in chemical reactions and catalysts?

\section{Method}

A cross-sectional survey was used to evaluate students' conceptual understanding level of energy, heat, temperature and enthalpy. According to Fraenkel, Wallen, \& Hyun, (2012) a cross-sectional survey, unlike a census, collects information from a sample drawn from a larger population. The information can be collected at a single time which may last up to several weeks. In this research, the population comprised public high school students, and the randomly selected sample was drawn from this population. The data were collected in a period of about fifteen days.

\subsection{Sampling Procedure and Participant Characteristics}

Data were collected from a randomly selected sample of 418 public high school students in the Anatolian side of Istanbul, which comprised 14 administrative districts, which made up the total accessible population. The selection process involved cluster and stratified random selection techniques. The 14 districts were coded and entered into the SPSS package program, and three were randomly selected. All the public high schools in the three districts were stratified according to the number of students in each, and 11 schools (4 in districts $\mathrm{A}$ and $\mathrm{B}$, and 3 in district $\mathrm{C}$ ) were randomly selected from among them. Finally, one class from each school was selected randomly. The participants were university candidates who were at the final stages of learning these subjects in high school. The CUT test was administered in 15 days under the supervision of both the teachers and researchers.

\subsection{Data Collection Tool}

The Conceptual Understanding Test (CUT) used in the pilot study included 30 multiple-choice questions which covered each related standard in the chemistry curriculum. The questions were validated by three high school chemistry teachers and three science education professors. After the suggested changes were made, the pilot study was carried out with 60 students. The responses to the 30 items in the CUT were analysed using SPSS, and the number of questions was reduced to 16 after those with low discrimination power were eliminated. The reliability of the final version of the CUT was established by a Cronbach's alpha coefficient $(\alpha)$ of .72, which proved it reliable because the rule of thumb in judging reliability is that it should be higher than .70 (Fraenkel et al., 2012). The CUT consisted of two-tier items: the first tier consisted of items that required a content response, and the second tier consisted of items of possible reasons for the response. The choices in the second tier, that is the reasons, included the correct choice as well as the misconceptions reported in previous research. In the second tier, the students had to choose from among the four given options, or write down their own reason if it was not provided. After the test was conducted, interviews were carried out with 10 randomly selected students, who were coded A to J.

\subsubsection{Evaluating CUT}

Students who answered both tiers correctly were given 2 points; those who answered one of the tiers (content or reason) correctly were given 1 point; and those who answered both tiers incorrectly were given 0 . When the content question was answered correctly but the reason question incorrectly, or vice versa, the level of understanding in that concept was classified as partial understanding (Peterson, Treagust, \& Garnett, 1989; Ültay \& Çalik, 2016). When both questions were answered incorrectly, it showed no understanding had taken place. To sum up, student responses were investigated in three levels:

(1) No understanding: the student answered both tiers incorrectly.

(2) Partial understanding or misconceptions: the student answered the content question correctly but provided an incorrect reason or, the students answered content incorrectly but provide a correct reason.

(3) Full understanding: the student answered the content and reason tier correctly. 
Table 1. Standards(S), Questions (Q) and Level of Understanding According to Student Percentages.

\begin{tabular}{|c|c|c|c|c|c|c|}
\hline \multirow[t]{4}{*}{$\mathrm{S}$} & \multirow[t]{4}{*}{ Q } & \multirow{4}{*}{ Standards } & \multicolumn{3}{|c|}{ Understanding Level } & \multirow{3}{*}{$\begin{array}{l}\text { Total } \\
(\%)\end{array}$} \\
\hline & & & 0 & 1 & 2 & \\
\hline & & & $\begin{array}{l}\text { Both tiers are } \\
\text { incorrect }\end{array}$ & $\begin{array}{l}\text { One of the tier is } \\
\text { correct }\end{array}$ & $\begin{array}{l}\text { Both tiers } \\
\text { are correct }\end{array}$ & \\
\hline & & & $\begin{array}{l}\text { No } \\
\text { understanding }\end{array}$ & $\begin{array}{l}\text { Partial Understanding } \\
\text { or Misconceptions }\end{array}$ & $\begin{array}{l}\text { Full } \\
\text { Understandi } \\
\text { ng }\end{array}$ & \\
\hline $\mathrm{S} 1$ & 1 & $\begin{array}{l}\text { Heat exchange, relationship with } \\
\text { temperature and preservation of } \\
\text { total heat }\end{array}$ & 27.6 & 54.4 & 19 & 100 \\
\hline $\mathrm{S} 2$ & 2,4 & $\begin{array}{l}\text { Measurement of heat and } \\
\text { temperature, difference between } \\
\text { heat and temperature }\end{array}$ & 19 & 74.3 & 6.7 & 100 \\
\hline $\mathrm{S} 3$ & $\begin{array}{l}5,13 \\
15\end{array}$ & $\begin{array}{l}\text { The relationship between heat, } \\
\text { temperature, mass and specific heat }\end{array}$ & 42.4 & 41.0 & 16.6 & 100 \\
\hline $\mathrm{S} 4$ & $\begin{array}{l}6 \\
14,16\end{array}$ & $\begin{array}{l}\text { Changes in heat, temperature and } \\
\text { enthalpy during change of state }\end{array}$ & 61.4 & 31.4 & 7.2 & 100 \\
\hline S5 & 8,10 & Heat exchange and its insulation & 21.2 & 56.0 & 22.8 & 100 \\
\hline S6 & 11 & $\begin{array}{l}\text { The relationship between Energy, } \\
\text { enthalpy and bonds in chemical } \\
\text { reactions }\end{array}$ & 72.7 & 16.8 & 11.2 & 100 \\
\hline S7 & 3,12 & $\begin{array}{l}\text { Energy and speed in chemical } \\
\text { reactions }\end{array}$ & 10.7 & 82.1 & 7.2 & 100 \\
\hline S8 & 9 & $\begin{array}{l}\text { Energy and catalysts in chemical } \\
\text { reactions }\end{array}$ & 64.6 & 18.5 & 17.5 & 100 \\
\hline
\end{tabular}

Standard codes, related questions and percentages of the level of understanding can be seen in Table 1. For instance, standard 1 (Heat exchange, relationship with temperature and preservation of total heat) is related to question 1 . The percentage of no understanding in S1 (question 1) is 27.6. The percentage of full understanding is $19 \%$. The rest of it is 54.4 for partial understanding or misconceptions. 'Measurement of heat and temperature, difference between heat and temperature' (coded as S2) is related to questions 2 and 4. The percentages of standards in more than one question are calculated as in S2. Accordingly, the number of students who got 0 from both questions in S2 (questions 2 and 4) was 79, which, when divided into the total number of students (79/418) produced 19 percent. An analysis of the responses revealed three distinctive patterns. The first is the lower percentage of full understanding in all standards, which ranged from $6.7 \%$ to $22.8 \%$. The second distinctive pattern is the high levels of no understanding (S3, S4, S6, and S7), which rose to $72.7 \%$ for $\mathrm{S} 6$. The last is the high levels of partial understanding in four standards compared to the other two categories (S1, S2, S5, and S8).

\section{Results}

In this part, students' level of conceptual understanding for conceptions on heat, temperature and enthalpy in chemical reactions are analysed according to data from both the CUT and interviews in terms of the standards. The study investigated the level of conceptual understanding in three categories: completely wrong or no answer, partially understanding or misconceptions and full understanding.

The analysed results showed that $19 \%$ of the students fully understood the concepts of standard 1 (S1), while $27.6 \%$ failed to understand them at all or did not give any answer. $53.4 \%$ of the students had partially understood or misunderstood. Some students believed that a substance with a higher temperature has a higher heat, the total heat of the mixture increases if the final temperature totals of the substances that make up a mixture are greater than initial temperature totals and heat transfer occurs from bigger substance to smaller substance. Misunderstanding of this concept has been identified by other studies (Kesidou \& Duit, 1993) The interviews with students A, C, and D further supported these findings; student A, for example, said 'if the total of temperature values of substances increases before they are mixed up, then the total heat also increases.' The results of the interviews also support previous studies (Niaz, 2006).

The number of students who misunderstood or partially understood was even higher for S2 than for S1 (74.3\%). Only $6.7 \%$ of the students fully understood S2, while $19 \%$ gave completely wrong or no answers whatsoever. Some of the students believed that heat and temperature can be used interchangeably and that the two concepts have the same meaning. The interviews provided further evidence that student conceptions of heat and temperature are ambiguous; Student A and D stated that heat and temperature are the same thing. Student D said that one can be used instead of the 
other, and heat and temperature are different units but measure the same thing. These beliefs were determined by earlier research as well (Grayson et al., 1995). Student A stated that heat exchange continues until total heats come to the same level. Student $\mathrm{C}$ said that heat and temperature are expression of energy in different units; they both measure the same thing.

$16.6 \%$ of the students were found to fully understand the concepts in S3, while $42.4 \%$ gave completely false or no answers. The remaining $41 \%$ either partially understood or misunderstood them. Some of the students believed that heat is only connected with temperature and mass. Others believed that absorbed heat depends only on specific heat, and if temperature is high, heat is absolutely high (it is not connected with mass). For these students, the substance whose temperature rises faster has absolutely absorbed more heat. Student $G$ stated in the interview that the heat of a substance which has high temperature is definitely higher than the substance which has low temperature; hence the heat of a hot metal spoon is definitely higher than a wooden spoon. This finding has been reported by other researchers (Kesidou \& Duit, 1993; Lewis \& Linn, 1994; Paik et al., 2007; Schönborn et al., 2014; Yeo \& Zadnik, 2001). Student J stated that: the heat of the oceans is lower than the heat of a glass of hot water. Student B and F stated nearly the same thing: the substance with a higher temperature has definitely absorbed more heat.

$7.2 \%$ of the students fully understood the concepts, while $61.4 \%$ of the students gave completely wrong or no answers, and $31.4 \%$ of the students partially understood or misunderstood the concepts in S4. Most of the students believed that exothermic or endothermic reactions cannot be mentioned in circumstances where temperature does not change. The terms exothermic and endothermic are only used for chemical reactions, not for physical changes. For example, students $\mathrm{H}$ and $\mathrm{C}$ believed that situations in which temperature is fixed cannot be endothermic or exothermic, and student I thought that enthalpy depends on ambient temperature. Moreover, a majority of the students thought that absorbed energy is not equal to released energy. In conceptions of heat exchange, most of the students believed that heat exchange continues until temperatures are even and that there is no heat exchange in constant temperature. They also believed that substances do not have any heat and temperature at $0^{\circ} \mathrm{C}$. For instance, student $\mathrm{A}$ and $\mathrm{K}$ respectively said that substances do not have any temperature at $0^{\circ} \mathrm{C}$, and substances do not have any heat at $0^{\circ} \mathrm{C}$. These results correlate with the results of previous studies (Ayyildiz \& Tarhan, 2012; Kartal, Öztürk, \& Yalvaç, 2011; Lewis \& Linn, 1994; Paik et al., 2007; Schönborn et al., 2014; Thomas \& Schwenz, 1998; Yeo \& Zadnik, 2001). Many students stated that melting of ice is just a physical change and it is neither exothermic nor endothermic because the terms of exothermic or endothermic are related to chemical reactions. A similar study of (de Vos \& Verdonk, 1986) reported that students had problems with exothermic and endothermic terms. Student H and K believed that as water freezes or melts, temperature does not change, namely water does not absorb or release heat so freezing of water or melting of ice cannot be exothermic or endothermic.

$22.8 \%$ of the students fully understood the concepts of S5 while $21.2 \%$ of the students gave completely wrong or no answers and $56 \%$ of the students showed partially understanding or misunderstanding. It was observed that quite a lot of the students had problems understanding heat exchange. It seems the students understood that if the temperature is increased the substance takes heat, but they failed to understand that if the temperature is decreased the substance releases heat. Some said that the substances take cold instead of giving heat. Moreover, some students believed that certain substances give heat steadily because of their nature.

As for heat isolation, some of the students believed that wool gives heat and increases temperature, just like (Driver, Guesne, \& Tiberghien, 1985) had found. Students H and B stated that heat isolation is done only to increase heat, and one feels cold if cold is absorbed. Student $\mathbf{J}$ stated that the released heat is not always equal to absorbed heat. These findings support the findings from (Paik et al., 2007) and (Schönborn et al., 2014).

The lowest conceptual understanding level in this study was found to be in S6 with $72.7 \%$. Only $11.2 \%$ of the students fully understood the concepts of the standard, and $16.1 \%$ partially understood or misunderstood. Some of the students believed that energy is needed in chemical reactions for formation of bonds and energy is released during bond breakage. Some researchers like (Barker \& Millar, 2000; Boo, 1998; Cachapuz \& Martins, 1987; Kind, 2004) found the same results earlier. Some other students believed that energy is needed in order to form something but everything can be destroyed by itself. In the interviews student I, K and F stated nearly the same thing: breaking bonds releases energy and creating bonds needs energy'. Student $\mathrm{C}$ stated that the heat in reactions is created by bonds' breaking and the energy of products in exothermic reactions is higher than the reactants. Student I believed that 'if broken bonds are stronger than formed bonds, heat is released'. (Boo \& Watson, 2001) and (Ayyildiz \& Tarhan, 2012) found the same misconceptions in their study. Student $\mathrm{F}$ stated that creating bonds is more difficult than breaking them. This misconception found earlier by (Barker \& Millar, 2000; Boo, 1998; Greenbowe \& Meltzer, 2003; Yalçınkaya et al., 2009).

It was determined that $7.2 \%$ of the students fully understood the concepts, while 10.7 gave completely wrong or no 
answers and $82.1 \%$ partially understood or misunderstood the concepts of S7. For example, some of the students believed that exothermic reactions are faster and the energy of the reactants increases in exothermic reactions. Some of other students believed that endothermic reactions are slower. These findings coincided with (Bodner, 1986; Cakmakci, 2005; Kolomuç \& Tekin, 2011; Sozbilir, 2001). In the interviews student G said that exothermic reactions end more quickly than endothermic reactions. Student A believed that reactions that need to gain heat occur slowly. Student $\mathrm{K}$ stated that gasoline gives more heat because it burns faster than wood, whereas Student H stated that because gasoline gives more heat it burns faster than wood.

It was determined that $17.5 \%$ of the students fully understood it, while $64.6 \%$ gave completely wrong or no answers and $17.9 \%$ partially understood or misunderstood the concepts of S8. A large group of the students mentioned that use of catalysts drops the activation energy, which reduces the energy required for the reaction. Although the students stated that using catalysts decreases the energy required for the completion of the chemical reaction. Some believed that catalysts make the reactions faster without requiring energy. These misunderstandings revealed by earlier researches (Balci, 2006; Cakmakci, 2005; Yalçınkaya, Taştan-Kırık, Boz, \& Yıldıran, 2012). In the interview student B stated that we can cook meals with lower heat by using catalyst. Student E stated that using catalyst gives extra energy to the substance and increases efficiency of the reaction.

\section{Discussion}

This research study investigated students' conceptual understanding level of certain concepts in thermodynamics. It is revealed according to the data from the CUT and the interviews with the students that most of the students had not grasped energy, heat, temperature and enthalpy concepts. Taking into consideration that they had been learning these topics since primary school repeatedly, we can infer that misunderstanding or lack of understanding on the subject of thermodynamics was alarmingly high.

The following topics seem to be particularly at critically low level of understanding:

- The relationship between energy, enthalpy and bonds in chemical reactions,

- Energy and catalysts in chemical reactions,

- Changes in heat, temperature and enthalpy during change of state (especially in this subject none of the students gave complete and correct explanation),

- Relationship between heat, temperature, mass and specific heat.

The study indicated that students had the lowest understanding level for the relationship between bonds, enthalpy and energy in chemical reactions, which can possibly be attributed to students' mis-(or lack of) understanding about bond breaking and formation. Students had problems with the enthalpy concept and they could not associate the relationship between enthalpy and these concepts although they know all the concepts by heart. Some students believed that if chemical bonds break, energy is released (Barker \& Millar, 2000; Ross, 1993). The misunderstanding might stem from the idea that energy is needed to make something, as a result of this which students think that making bonds requires some energy (Boo, 1998).

Another issue that students had great difficulty was the relationship between heat, temperature, mass and specific heat. The areas of misunderstanding were again consistent with previous research as many students did not think that heat is a kind of energy and they believed heat and temperature are the same concepts (Wiser, 1986; Wiser \& Carey, 1983) Moreover, they confused heat capacity and specific heat. This may have caused them to fail to understand the heat exchange and heat transfer mechanisms (Harrison, Grayson, \& Treagust, 1999; Paik et al., 2007; Wiser \& Carey, 1983). The students could not relate all four concepts but just two and they believed others have no effect. They believed that heat is affected just by temperature but not by mass and specific heat.

Students also had a very low level of understanding about energy and catalysts in chemical reactions. Although they knew the definition of the catalyst, according to the interviews they had difficulty understanding that catalysts reduce enthalpy and activation energy. They thought that a catalyst gives extra energy to the reaction and increases the number of collisions magically. The misunderstanding might result from the short and superficial definitions of catalysis in textbooks (Van Driel, Verloop, \& de Vos, 1998) and students' failure to fully comprehend the concepts of collision theory and chemical kinetics (Balci, 2006).

The study also revealed that students had an insufficient conceptual understanding level about changing of heat, changes in temperature and enthalpy during phase change, and conservation of energy. They had difficulty distinguishing the concepts of heat and temperature and understanding their relationship (Carlton, 2000) Instead, they had an alternative concept that covers some of the characteristics of heat and some of temperature (Wiser, 1986).

The results indicated that students' understanding of the above mentioned concepts was generally either wrong or 
incomplete. Determining the conceptual understanding level of students can be considered to be the first step of a longitudinal study aiming to promote the engagement of students in learning process. The problems students face when studying the concepts of thermodynamics suggest that these concepts are not so easy for them to grasp and they need to be handled explicitly during teaching and learning process.

\section{References}

Anderson, E. E., Taraban, R., \& Sharma, M. (2005). Implementing and assessing computer-based active learning materials in introductory thermodynamics. International Journal of Engineering Education, 21(6), 1168.

Ausubel, D. P., Stager, M., \& Gaite, A. J. H. (1968). Retroactive Facilitation in Meaningful Verbal Learning. Journal of Educational Psychology, 59(4), 250. http://dx.doi.org/10.1037/h0025943

Ayyildiz, Y., \& Tarhan, L. (2012). The effective concepts on students' understanding of chemical reactions and energy. Hacettepe Hacettepe University Journal of Education, 42(42), 72-83.

Balci, C. (2006). Conceptual change text oriented instruction to facilitate conceptual change in rate of reaction concepts. Unpublished doctoral dissertation, Middle East Technical University.

Barker, V., \& Millar, R. (2000). Students' reasoning about basic chemical thermodynamics and chemical bonding: what changes occur during a context-based post-16 chemistry course? International Journal of Science Education, 22(11), 1171-1200. http://dx.doi.org/10.1080/09500690050166742

Baser, M. (2006). Fostering conceptual change by cognitive conflict based instruction on students' understanding of heat and temperature concepts. Eurasia Journal of Mathematics, Science and Technology Education, 2(2), 96-114.

Ben-Zvi, R., Eylon, B., \& Silberstein, J. (1988). Theories, principles and laws. Education in chemistry, 25(3), 89-92.

Bergquist, W., \& Heikkinen, H. (1990). Student ideas regarding chemical equilibrium: What written test answers do not reveal. Journal of Chemical Education, 67(12), 1000. http://dx.doi.org/10.1021/ed067p1000

Bodner, G. M. (1986). Constructivism: A theory of knowledge. Journal of Chemical Education, 63(10), 873. http://dx.doi.org/10.1021/ed063p873

Boo, H. K. (1998). Students' understandings of chemical bonds and the energetics of chemical reactions. Journal of $\begin{array}{lllrl}\text { Research in } & \text { Science } & \text { Teaching, } & 35(5), & 569-581 .\end{array}$ http://dx.doi.org/10.1002/(SICI)1098-2736(199805)35:5<569::AID-TEA6>3.0.CO;2-N

Boo, H. K., \& Watson, J. (2001). Progression in high school students'(aged 16-18) conceptualizations about chemical reactions in solution. Science Education, 85(5), 568-585. http://dx.doi.org/10.1002/sce.1024

Brook, A., Briggs, H., Bell, B., \& Driver, R. (1984). Aspects of secondary students' understanding of heat: Summary report: University, Centre for Studies in Science and Mathematics Education.

Cachapuz, A., \& Martins, I. (1987). High School Students' ideas about Energy of Chemical Reactions. Document Resume ED 293686 SE 048 927, 60.

Cahyadi, M. V., \& Butler, P. H. (2004). Undergraduate students' understanding of falling bodies in idealized and real world situations. Journal of Research in Science Teaching, 41(6), 569-583. http://dx.doi.org/10.1002/tea.20018

Cakmakci, G. (2005). A cross-section study of the understanding of chemical kinetics among Turkish secondary and undergraduate students. Doctoral dissertation, University of Leeds.

Calik, M., \& Ayas, A. (2005). A comparison of level of understanding of eighth - grade students and science student teachers related to selected chemistry concepts. Journal of Research in Science Teaching, 42(6), 638-667. http://dx.doi.org/10.1002/tea.20076

Carlton, K. (2000). Teaching about heat and temperature. Physics Education, 35(2), 101. http://dx.doi.org/10.1088/0031-9120/35/2/304

Carson, E., \& Watson, J. (2002). Undergraduate students' understandings of entropy and Gibbs free energy. University Chemistry Education, 6(1), 4-12.

Chiu, M. H. (2007). A national survey of students' conceptions of chemistry in Taiwan. International Journal of Science Education, 29(4), 421-452. http://dx.doi.org/10.1080/09500690601072964

Cotignola, M. I., Bordogna, C., Punte, G., \& Cappannini, O. M. (2002). Difficulties in Learning Thermodynamic Concepts Are They Linked to the Historical Development of this Field? Science \& Education, 11(3), 279-291. http://dx.doi.org/10.1023/A:1015205123254 
Cox, A. J., Belloni, M., Dancy, M., \& Christian, W. (2003). Teaching thermodynamics with Physlets ${ }^{\circledR}$ in introductory physics. Physics Education, 38(5), 433. http://dx.doi.org/10.1088/0031-9120/38/5/309

Darmofal, D. L., Soderholm, D. H., \& Brodeur, D. R. (2002). Using concept maps and concept questions to enhance conceptual understanding. Paper presented at the Frontiers in Education, 2002. FIE 2002. 32nd Annual. http://dx.doi.org/10.1109/fie.2002.1157954

de Vos, W., \& Verdonk, A. H. (1986). A new road to reactions: Part III. Teaching the heat effect of reactions. Journal of Chemical Education, 63(11), 972. http://dx.doi.org/10.1021/ed063p972

Driver, R., Asoko, H., Leach, J., Scott, P., \& Mortimer, E. (1994). Constructing scientific knowledge in the classroom. Educational researcher, 23(7), 5-12. http://dx.doi.org/10.3102/0013189X023007005

Driver, R., Guesne, E., \& Tiberghien, A. (1985). Some features of children's ideas and their implications for teaching. Children's ideas in science, 193-201.

Duit, R. (1999). Conceptual change approaches in science education. New perspectives on conceptual change, 263-282.

Duschl, R. A., \& Gitomer, D. H. (1991). Epistemological perspectives on conceptual change: Implications for educational practice. Journal of Research in Science Teaching, 28(9), 839-858. http://dx.doi.org/10.1002/tea.3660280909

Erickson, G. L. (1979). Children's conceptions of heat and temperature. Science Education, 63(2), 221-230. http://dx.doi.org/10.1002/sce.3730630210

Erickson, G. L. (1980). Children's viewpoints of heat: A second look. Science Education, 64(3), 323-336. http://dx.doi.org/10.1002/sce.3730640307

Fleer, M. (1999). Children's alternative views: alternative to what? International Journal of Science Education, 21(2), 119-135. http://dx.doi.org/10.1080/095006999290741

Fraenkel, J., Wallen, N., \& Hyun, H. (2012). How to Design and Evaluate Research in Education (8th edt.). New York: McGram-Hill Companies.

Goedhart, M. J., \& Kaper, W. (2002). From chemical energetics to chemical thermodynamics. Chemical education: Towards research-based practice, 339-362.

Grayson, D., Harrison, A., \& Treagust, D. (1995). A multidimensional study of changes that occurred during a short course on heat and temperature. Paper presented at the Proceedings of Southern African Association for Research in Mathematics and Science Education 3rd Annual Meeting.

Greenbowe, T., \& Meltzer, D. (2003). Student learning of thermochemical concepts in the context of solution calorimetry. International Journal of Science Education, 25(7), 779-800. http://dx.doi.org/10.1080/09500690305032

Harrison, A. G., Grayson, D. J., \& Treagust, D. F. (1999). Investigating a grade 11 student's evolving conceptions of heat and temperature. Journal of Research in Science Teaching, 36(1), 55-87. http://dx.doi.org/10.1002/(SICI)1098-2736(199901)36:1<55::AID-TEA5>3.0.CO;2-P

Herron, J. D. (1996). The Chemistry Classroom: Formulas for Successful Teaching: ERIC.

Huang, M., \& Gramoll, K. (2004). Online interactive multimedia for engineering thermodynamics. Paper presented at the ASEE Annual Conf. Proc., Salt Lake City, UT.

Jasien, P. G., \& Oberem, G. E. (2002). Understanding of elementary concepts in heat and temperature among college students and K-12 teachers. Journal of Chemical Education, 79(7), 889. http://dx.doi.org/10.1021/ed079p889

Junglas, P. (2006). Simulation programs for teaching thermodynamics. Global J. of Engng. Educ, 10(2), 175-180.

Kabapınar, F. (2006). Teaching Science And Designing Science Textbooks In The Line With Constructivist Views On Learning: A textbook unit on Solubility. Eurasian Journal of Educational Research, 22, 139-149.

Kartal, T., Öztürk, N., \& Yalvaç, H. G. (2011). Misconceptions of science teacher candidates about heat and temperature. Procedia-Social and Behavioral Sciences, $15, \quad 2758-2763$. http://dx.doi.org/10.1016/j.sbspro.2011.04.184

Kesidou, S., \& Duit, R. (1993). Students' conceptions of the second law of thermodynamics - an interpretive study. Journal of Research in Science Teaching, 30(1), 85-106. http://dx.doi.org/10.1002/tea.3660300107

Kind, V. (2004). Beyond appearances: Students' misconceptions about basic chemical ideas. School of Education, Durham University, UK. Retrieved Sep, 25, 2009. 
Kolomuç, A., \& Tekin, S. (2011). Chemistry teachers' misconceptions concerning concept of chemical reaction rate. Eurasian Journal of Physics and Chemistry Education, 3(2), 84-101.

Krishnan, S. R., \& Howe, A. C. (1994). The mole concept: Developing an instrument to assess conceptual understanding. Journal of Chemical Education, 71(8), 653. http://dx.doi.org/10.1021/ed071p653

Krummel, R., Sunal, D. W., \& Sunal, C. S. (2007). Helping Students Reconstruct Conceptions of Thermodynamics: Energy and Heat. Science Activities: Classroom Projects and Curriculum Ideas, 44(3), 106-112. http://dx.doi.org/10.3200/sats.44.3.106-112

Laburú, C. E., \& Niaz, M. (2002). A Lakatosian framework to analyze situations of cognitive conflict and controversy in students' understanding of heat energy and temperature. Journal of Science Education and Technology, 11(3), 211-219. http://dx.doi.org/10.1023/A:1016064301034

Lewis, E. L., \& Linn, M. C. (1994). Heat energy and temperature concepts of adolescents, adults, and experts: Implications for curricular improvements. Journal of Research in Science Teaching, 31(6), 657-677. http://dx.doi.org/10.1002/tea.3660310607

Linn, M. C., \& Songer, N. B. (1991). Teaching thermodynamics to middle school students: What are appropriate cognitive demands? Journal of Research in Science Teaching, 28(10), 885-918.

McDermott, L. (2003). Improving student learning in sciences. Physical Science News, 4(2), 6-10.

Meltzer, D. E. (2004). Investigation of students' reasoning regarding heat, work, and the first law of thermodynamics in an introductory calculus-based general physics course. American Journal of Physics, 72(11), 1432-1446. http://dx.doi.org/10.1119/1.1789161

Mulop, N., Yusof, K. M., \& Tasir, Z. (2012). A review on enhancing the teaching and learning of thermodynamics. Procedia-Social and Behavioral Sciences, 56, 703-712. http://dx.doi.org/10.1016/j.sbspro.2012.09.706

Niaz, M. (2006). Can the study of thermochemistry facilitate students' differentiation between heat energy and temperature? Journal of Science Education and Technology, 15(3-4), 269-276. http://dx.doi.org/10.1007/s10956-006-9013-7

Olgun, Ö. S. Ç. (2008). Examining the fifth graders' understanding of heat and temperature concepts via concept mapping. Hacettepe University Journal of Education, 34(34).

Osborne, R., \& Freyberg, P. (1985). Learning in Science. The Implications of Children's Science: ERIC.

Özkaya, A. R., Üce, M., Saricayir, H., \& Sahin, M. (2006). Effectiveness of conceptual change-oriented teaching strategy to improve students' understanding of galvanic cells. Journal of Chemical Education, 83(11), 1719. http://dx.doi.org/10.1021/ed083p1719

Paik, S. H., Cho, B. K., \& Go, Y. M. (2007). Korean 4 - to 11 - year - old student conceptions of heat and temperature. Journal of Research in Science Teaching, 44(2), 284-302. http://dx.doi.org/10.1002/tea.20174

Palmer, D. H. (1999). Exploring the link between students' scientific and nonscientific conceptions. Science Education, 83(6), 639-653. http://dx.doi.org/10.1002/(SICI)1098-237X(199911)83:6<639::AID-SCE1>3.0.CO;2-O

Patron, F. (1997). Conceptual understanding of thermodynamics: a study of undergraduate and graduate students.

Peterson, R. F., Treagust, D. F., \& Garnett, P. (1989). Development and application of a diagnostic instrument to evaluate grade - 11 and - 12 students' concepts of covalent bonding and structure following a course of instruction. Journal of Research in Science Teaching, 26(4), 301-314. http://dx.doi.org/10.1002/tea.3660260404

Pétursson, S. (2003). Three Forms of Energy. Journal of Chemical Education, 80(7), 776. http://dx.doi.org/10.1021/ed080p776

Pfundt, H., \& Duit, R. (1988). Bibliography. Students' alternative frameworks and science education.

Piaget, J. (1951). The child's conception of the world (Vol. 213): Rowman \& Littlefield.

Piaget, J. (1985). The equilibration of cognitive structures: The central problem of intellectual development: University of Chicago Press.

Pine, K., Messer, D., \& St. John, K. (2001). Children's misconceptions in primary science: a survey of teachers' views. Research in Science \& Technological Education, 19(1), 79-96. http://dx.doi.org/10.1080/02635140120046240

Posner, G. J., Strike, K. A., Hewson, P. W., \& Gertzog, W. A. (1982). Accommodation of a scientific conception: Toward a theory of conceptual change. Science Education, 66(2), 211-227.

http://dx.doi.org/10.1002/sce.3730660207 
Prawat, R. S. (1989). Promoting access to knowledge, strategy, and disposition in students: A research synthesis. Review of educational research, 59(1), 1-41. http://dx.doi.org/10.3102/00346543059001001

Ross, K. (1993). There is no energy in food and fuels, but they do have fuel value. School Science Review, 75(271), 39-47.

Roth, W. M., \& Lucas, K. B. (1997). From "truth" to "invented reality": A discourse analysis of high school physics students' talk about scientific knowledge. Journal of Research in Science Teaching, 34(2), 145-179. http://dx.doi.org/10.1002/(SICI)1098-2736(199702)34:2<145::AID-TEA4>3.0.CO;2-T

Schönborn, K., Haglund, J., \& Xie, C. (2014). Pupils' early explorations of thermoimaging to interpret heat and temperature. Journal of Baltic Science Education, 13(1), 118-132.

Smith, P. L., \& Ragan, T. J. (1999). Instructional design: Wiley New York, NY.

Sokrat, H., Tamani, S., Moutaabbid, M., \& Radid, M. (2014). Difficulties of Students from the Faculty of Science with Regard to Understanding the Concepts of Chemical Thermodynamics. Procedia-Social and Behavioral Sciences, 116, 368-372. http://dx.doi.org/10.1016/j.sbspro.2014.01.223

Sozbilir, M. (2001). A study of undergraduates' understandings of key chemical ideas in thermodynamics. University of York.

Sozbilir, M. (2003). A review of selected literature on students' misconceptions of heat and temperature. Boğaziçi University Journal of Education, 20(1), 25-41.

Sözbilir, M. (2004). What makes physical chemistry difficult? Perceptions of Turkish chemistry undergraduates and lecturers. Journal of Chemical Education, 81(4), 573. http://dx.doi.org/10.1021/ed081p573

Tharp, R. G., \& Gallimore, R. (1988). Rousing minds to life: Cambridge: Cambridge University Press.

Thomas, P. L., \& Schwenz, R. W. (1998). College physical chemistry students' conceptions of equilibrium and fundamental thermodynamics. Journal of Research in Science Teaching, 35(10), 1151-1160. http://dx.doi.org/10.1002/(SICI)1098-2736(199812)35:10<1151::AID-TEA6>3.0.CO;2-K

Tobin, K., Tippins, D., \& Gallard, A. (1994). Research on instructional strategies for teaching science.[In DL Gabel (Ed.), Handbook of research on science teaching and learning (pp. 45-93). New York: Macmillan.

Ültay, N., \& Çalik, M. (2016). A Comparison of Different Teaching Designs of 'Acids and Bases' Subject. Eurasia Journal of Mathematics, Science \& Technology Education, 12(1), 57-86.

Van Driel, J. H., Verloop, N., \& de Vos, W. (1998). Developing science teachers' pedagogical content knowledge. Journal of Research in Science Teaching, 35(6), 673-695. http://dx.doi.org/10.1002/(SICI)1098-2736(199808)35:6<673::AID-TEA5>3.3.CO;2-9

Vygotsky, L. S. (1980). Mind in society: The development of higher psychological processes: Harvard university press.

Wiggins, G. P., McTighe, J., Kiernan, L. J., \& Frost, F. (1998). Understanding by design: Association for Supervision and Curriculum Development Alexandria, VA.

Wiser, M. (1986). The Differentiation of Heat and Temperature: An Evaluation of the Effect of Microcomputer Teaching on Students' Misconceptions. Technical Report 87-5.

Wiser, M., \& Carey, S. (1983). When heat and temperature were one. Mental models, 267-297.

Yalçınkaya, E., Taştan-Kırık, Ö., Boz, Y., \& Yıldıran, D. (2012). Is case-based learning an effective teaching strategy to challenge students' alternative conceptions regarding chemical kinetics? Research in Science \& Technological Education, 30(2), 151-172. http://dx.doi.org/10.1080/02635143.2012.698605

Yalçınkaya, E., Taştan, Ö., \& Boz, Y. (2009). High School Students' Conceptions about Energy in Chemical Reactions. Journal of Pamukkale University Education Faculty, 26, 1-11.

Yeo, S., \& Zadnik, M. (2001). Introductory thermal concept evaluation: Assessing students' understanding. The Physics Teacher, 39(8), 496-504. 


\section{Appendix}

\section{Sample Questions from Conceptual Understanding Test.}

Q15. Which of the statements is true about the Pacific Ocean at $5^{\circ} \mathrm{C}$, and a glass of water from the Pacific Ocean that is heated up to $95^{\circ} \mathrm{C}$ ?

A. The heat of the water in the glass is higher.

B. The heat of the Pacific Ocean is higher.

C. We can't compare the heat of the Pacific Ocean and the heat of the water in the glass.

D. The heat of the Pacific Ocean and the heat of the water in the glass are the same.

The reason is:

1. Substances with higher temperature also have higher heat.

2. There is no connection between temperature and heat; heat increases when mass increases.

3. The heat is the same for both the water in the glass and Pacific Ocean because they are the same substance.

4. There is no connection between heat, temperature and mass.

5. None. I think the reason is:

Q7. Two different reaction occurred in the beaker A and B. The position before the reaction and after the reaction is seen below for each beaker. According to this;
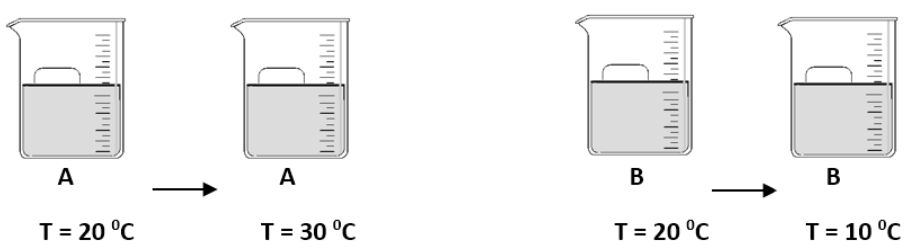
A. The reaction in the beaker $\mathrm{A}$ is faster than $\mathrm{B}$.
B. The reaction in the beaker $\mathrm{B}$ is faster than $\mathrm{A}$.
C. The energy of the products is greater after the reaction in the beaker A.
D. We cannot make any comment about the reaction rate of beakers.

The reason is:

1. Exothermic reactions occurs faster.

2. Endothermic reactions occurs faster.

3. The energy of reactants decreases in exothermic reactions.

4. There is no relationship between the reaction rate and enthalpy.

5. None. I think the reason is:

Q3. Under the same conditions (temperature, pressure and amount), the same reaction is occurred with catalyst in the first beaker and without catalyst in the second beaker. According to this, which of the followings is true?
A. The first reaction needs less energy to occur.
B. The first beaker has higher temperature after the reaction.
C. We cannot make any comment about the temperature of beakers.
D. The amount of the products are the same for both beakers.

The reason is:

1. Using catalyst decreases the enthalpy.

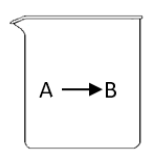

With catalyst

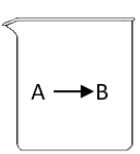

Without catalyst

2. Using catalyst effects the enthalpy of different reactions in a different way.

3. Using catalyst increases the efficiency of the reaction.

4. Using catalyst decreases activation energy.

5. None. I think the reason is:

\section{(cc) EY}

This work is licensed under a Creative Commons Attribution 3.0 License. 